\title{
Assessing the Social Economic and Physical Vulnerabilities to Gamalama Volcano
}

\author{
Estuning Tyas Wulan Mei \\ Faculty of Geography, \\ Gadjah Mada University \\ Yogyakarta, Indonesia \\ Ifa Meilyana Sari \\ Faculty of Geography, \\ Gadjah Mada University \\ Yogyakarta, Indonesia \\ Alia Fajarwati \\ Faculty of Geography, \\ Gadjah Mada University \\ Yogyakarta, Indonesia \\ Diwya Safitri \\ Faculty of Geography, \\ Gadjah Mada University \\ Yogyakarta, Indonesia
}

Corresponding email: estu.mei@geo.ugm.ac.id

\begin{abstract}
Gamalama Volcano is stratovolcano located in Ternate Island. Gamalama has been intermittently active for many decades and the biggest eruption history happened in $\mathbf{1 7 7 5}$ which killed about 141 people and destroyed some villages around the volcano. As a main city, Ternate has more complete facilities and good accessibility, better than other islands. From demographic perspective, Ternate has a high population density living in the flanks of Gamalama Volcano, especially in the east and south part. Since Ternate has limited natural resources, it creates a high dependence to other islands. The aims of this research is to assess social-economic and physical vulnerability towards volcanic hazards of Gamalama Volcano. Secondary data from Potensi Desa combined with field observations were used in this research. We used Spatial Multi-Criteria Evaluation (SMCE) for analyzing the vulnerabilities. The results of total vulnerability map analysis show that the high vulnerable areas are mostly located in the western part of the Island which is match with two other vulnerabilities map which are economic and social vulnerability.
\end{abstract}

Keyword-Vulnerability, ternate, gamalama, volcano.

\section{INTRODUCTION}

Indonesia is one of the countries that have a wide variety of threats and natural disasters ranging from small to large scale (Marfai and King, 2008; Sri Hadmoko, 2009). From 1980 to 2008, the number of cataclysmic events in Indonesia reached 293 disaster events with 189615 casualties (UNISDR, 2011). From 1998 to 2008, various major disasters that occurred in Indonesia caused economic losses of up to 7.3 trillion rupiahs.
Disasters in Indonesia, as elsewhere in the world, are caused by two main factors (Lassa, 2010; Wisner, Gaillard and Kelman, 2012): (1) the potential hazards and (2) the socioeconomic conditions of the majority of the population who are vulnerable to disasters. Today, about 500 million people worldwide live in volcanic regions with the distance is less than $100 \mathrm{~km}$ (Chester et al., 2000; Small and Naumann, 2001). The most frequent volcanic disasters hit the poor and gender minorities, the disabled, the elderly, and people do not have access to resources and means of protection (Balgos, Gaillard and Sanz, 2012; Mei and Lavigne, 2012; Mei et al., 2013). The combination of these two factors causing large potential risks in the area around volcanoes.

Indonesia has more than 100 active volcanoes scattered in both major islands (Sumatra, Java, Sulawesi) and in small islands (Maluku, NTT, Ambon, etc.). Gamalama Volcano is one example of volcanoes located on a small island, the island of Ternate. The In terms of the potential hazards of volcanoes, ESDM Ministry Data mentions that Gamalama volcano has a history of eruptions from 1538 to 2014. Gamalama volcano eruption in 1538 was the first recorded eruption, whereas a major eruption occurred in 1775. In that year, Gamalama volcano eruption formed a maar around the village Soela Takomi within $1.5 \mathrm{~km}$ southwest of the current Takomi Village location. Gogarten (1918) stated that the formation of the hole known as Tolire Jaha (Big Hole), preceded by a large-scale tectonic earthquake. The eruption in 1775 was the largest Gamalama Volcano disaster that produced Tolire Jaha and Small Tolire (Small Hole) maar crater with 141 victims buried 
together with the disappearance of the Soela Takomi Village. Gamalama volcano eruption in December 2014 occurred several times by bursts of volcanic ash as high as 1,700 meters from the summit. The impact of the eruption, among others: the occurrence of ash on the City of Ternate and the Sultan Babullah Airport closures for three days.

Gamalama Volcano is located on Ternate Island, it has distinctiveness archipelago area such as insularity, dependence with other regions, limited natural resources, high population, has the complete infrastructure and public facilities as the urban areas. The high quantity of elements of risk and the complexity of the of these vulnerability aspects give an impact on the increased risk of the region to the threat of volcanic disasters.

Disaster Risk Reduction can be implemented by reducing the threat and/or reducing vulnerability and increasing capacity. This research whose aim is to assess the socioeconomic and physical vulnerability against Gamalama Volcano's volcanic hazards is part of a research scheme entitled The Integration of Spatial, Ecology and Regional Complex Approach in Gamalama Volcano Disaster Risk Reduction.

\section{METHOD}

The study of the vulnerability is done by adopting Spatial Multi-Criteria Evaluation (SMCE) on GIS software ILWIS 3.3. The unit of analysis on this vulnerability assessment is village. The value of vulnerability is the result from a compilation of physical, social and economic vulnerabilities. SMCE is selected as an analytical tool because it can combine spatial data (GIS) and non-spatial data GIS (Carver, 1991; Malczewski, 2004).

Spatial data obtained from the extraction of high resolution remote sensing data and topographic map, while the nonspatial data obtained from data on Village Potential-2014 and equipped with Sub-district in Figures-2015 data. In addition, semi-structured interviews using a questionnaire was also conducted to make the weighting rank for each parameter of vulnerabilities. The data used includes physical, social, and economic parameters (Table I) as follows:

TABLE I. PARAMETERS FOR PHYSICAL, SOCIAL AND ECONOMIC VULNERABILITIES ASSESSMENT OF TERNATE ISLAND

\begin{tabular}{|c|c|c|}
\hline Vulnerability & Parameter & Variable \\
\hline \multirow{9}{*}{ SOCIAL } & \multirow{2}{*}{$\begin{array}{l}\text { Demographic } \\
\text { Condition }\end{array}$} & Dependency Ratio \\
\hline & & Population Density \\
\hline & \multirow{7}{*}{$\begin{array}{l}\text { Education and } \\
\text { Knowledge }\end{array}$} & $\begin{array}{l}\text { Number of Formal Institution } \\
\text { (Elementary - High Schools) }\end{array}$ \\
\hline & & $\begin{array}{l}\text { Infrastructure Capacity } \\
\text { Improvement }\end{array}$ \\
\hline & & Educational Package Activities \\
\hline & & Skills Training Institutions \\
\hline & & Economic Capacity Improvement \\
\hline & & $\begin{array}{l}\text { Civil Society Capacity } \\
\text { Improvement }\end{array}$ \\
\hline & & Signal Strength of cell phone / \\
\hline
\end{tabular}

\begin{tabular}{|c|c|c|}
\hline Vulnerability & Parameter & Variable \\
\hline & & mobile phone \\
\hline & & Households Own TV \\
\hline & Health & $\begin{array}{l}\text { Number of health facilities (Health } \\
\text { Center, Supported Health Center, } \\
\text { Child's Health Center, Physician, } \\
\text { Midwife) }\end{array}$ \\
\hline & & Number of Difable \\
\hline & & The number of deprived people \\
\hline & Institution & $\begin{array}{l}\text { The existence of the Village } \\
\text { Consultative Body }\end{array}$ \\
\hline & & $\begin{array}{l}\text { Total Users of Health Insurance } \\
\text { (BPJS) }\end{array}$ \\
\hline & Social Insurance & $\begin{array}{l}\text { Number of Health Insurances } \\
\text { (Jamkesda dan Jamkesmas) users }\end{array}$ \\
\hline \multirow{8}{*}{ ECONOMIC } & $\begin{array}{l}\text { People's } \\
\text { Livelihood }\end{array}$ & People's Livelihood \\
\hline & \multirow{2}{*}{$\begin{array}{l}\text { Existence of } \\
\text { Financial } \\
\text { Institutions }\end{array}$} & Number of Bank \\
\hline & & Number of Cooperation \\
\hline & \multirow{5}{*}{$\begin{array}{l}\text { People's } \\
\text { Livelihood }\end{array}$} & The existence of industrial activity \\
\hline & & Number of market \\
\hline & & Number of minimarket \\
\hline & & Number of grocery \\
\hline & & Number of cafe/restaurant \\
\hline \multirow{7}{*}{ PHYSICAL } & Building Density & $\begin{array}{l}\text { Ratio of settlement with the total } \\
\text { area }\end{array}$ \\
\hline & Road Condition & Average of the road's width \\
\hline & \multirow{5}{*}{$\begin{array}{l}\text { Communication } \\
\text { Network }\end{array}$} & $\begin{array}{l}\text { The availability of cellular } \\
\text { transmission }\end{array}$ \\
\hline & & $\begin{array}{l}\text { Number of Household using } \\
\text { telephone }\end{array}$ \\
\hline & & $\begin{array}{l}\text { Number of Household using } \\
\text { electricity }\end{array}$ \\
\hline & & Number of Household own TV \\
\hline & & $\begin{array}{l}\text { Signal Strength of cell phone / } \\
\text { mobile phone }\end{array}$ \\
\hline
\end{tabular}

Source : Cutter et al., 2003 with modification.

The weighting regard to the opinion of village government representatives, community representatives, as well as the staff of the Regional Disaster Management Agency and then calculated by the method of ranking and then processed with ILWIS. The weight of social vulnerability parameters in this study are in Table II.

TABLE II. THE WEIGHTING RESULT OF SOCIAL, PHYSICAL AND ECONOMIC VULNERABILITIES

\begin{tabular}{|c|c|c|c|c|c|}
\hline Vulnerability & Rank & Weight & Variable & Rank & Weight \\
\hline \multirow{5}{*}{ Social } & \multirow{5}{*}{2} & \multirow{5}{*}{0.28} & $\begin{array}{l}\text { Demographic } \\
\text { Condition }\end{array}$ & 1 & 0.36 \\
\hline & & & $\begin{array}{l}\text { Education and } \\
\text { Knowledge }\end{array}$ & 3 & 0.09 \\
\hline & & & Health & 1 & 0.36 \\
\hline & & & Institution & 4 & 0.04 \\
\hline & & & Social Insurance & 2 & 0.16 \\
\hline \multirow[b]{2}{*}{ Economic } & \multirow[b]{2}{*}{1} & \multirow[b]{2}{*}{0.61} & $\begin{array}{l}\text { People's } \\
\text { Livelihood }\end{array}$ & 2 & 0.28 \\
\hline & & & $\begin{array}{l}\text { Existence of } \\
\text { Financial } \\
\text { Institutions }\end{array}$ & 3 & 0.11 \\
\hline
\end{tabular}




\begin{tabular}{|c|c|c|c|c|c|}
\hline Vulnerability & Rank & Weight & Variable & Rank & Weight \\
\hline & & & $\begin{array}{l}\text { Regional } \\
\text { Economic } \\
\text { Activities }\end{array}$ & 1 & 0.61 \\
\hline \multirow{3}{*}{ Physical } & \multirow{3}{*}{3} & \multirow{3}{*}{0.11} & Building Density & 1 & 0.61 \\
\hline & & & Road Condition & 2 & 0.28 \\
\hline & & & $\begin{array}{l}\text { Communication } \\
\text { Network }\end{array}$ & 3 & 0.11 \\
\hline
\end{tabular}

\section{FINDING AND DISCUSSION}

Vulnerability is a characteristic or a conditions of society or a system that affect the size of the damage impact caused by the hazard or disaster (Adger et al., 2004). Vulnerability is influenced by three aspects: physical, socio-economic, and environmental. These three aspects are factors influencing the level of vulnerability as well as a element of risk or risky aspects affected by disaster. Parameters are set with due regard to the factors that influence the vulnerability at the individual/household, community, region or institution levels. In this study, a vulnerability assessment relating to the eruption of Gamalama Volcano focused on the physical, the social and economic aspects with the village as the unit of analysis. The method used to assess the vulnerability is Spatial Multi Criteria Evaluation (SMCE). SMCE is a tool to make decisions based on Analytical Hierarchical Process (AHP) combined with Geographic Information Systems (GIS) (Carver, 1991; Van Westen, 2016).

\section{A. Social Vulnerability}

Social vulnerability is a vulnerability that is measured by the social conditions of society. The social aspects are difficult to measure, and therefore are often overlooked in the assessment of disaster losses. Factors used to measure social vulnerability are vary depending on hazard characteristics (Adger et al., 2004).

The value of social vulnerability in Ternate Island is obtained after data processing and weighting for each variable and parameter. The calculations show that the majority of villages in Ternate Island has a high social vulnerability (36 villages), while 17 villages have moderate vulnerabilities and the rest (6 villages) have low susceptibility. Village with the highest social vulnerability value is Santiong Village (District of Ternate Tengah) with vulnerability index 0.85 and villages with the lowest social vulnerability is Kalumata Village (District of Ternate Selatan) with 0.26 vulnerability index.

Based on the calculation of the index of vulnerability, social sectors still require considerable attention in disaster risk reduction. Increasing the capacity of communities in the social field accompanied by the development of social infrastructure can be an alternative to reduce the social vulnerability of a community.

Considering the many villages that have a high social vulnerability, it is necessary to give priority to villages which need attention first. Villages which should take priority in advance are a villages with a high social vulnerability and are in Hazard Prone Area III, followed by Hazard Prone Area II and Hazard Prone Area I because have a greater vulnerability to disasters.

TABLE III. VILLAGE OF THE SOCIAL VULNERABILITY AND VULNERABILITY TO VOLCANO GAMALAMA ERUPTION

\begin{tabular}{|l|l|l|}
\hline \multicolumn{1}{|c|}{ Village } & \multicolumn{1}{c|}{ Social Vulnerability } & \multicolumn{1}{c|}{ Zone } \\
\hline Loto & High & III, II, I \\
\hline Togafo & High & II, I \\
\hline Takome & Middle & II, I \\
\hline Tobololo & Middle & III, II, I \\
\hline Bula & Middle & II, I \\
\hline Kurlaba & High & III, II, I \\
\hline Sango & High & III, II \\
\hline Tabam & High & III, II, I \\
\hline Tubo & Middle & III, II, I \\
\hline
\end{tabular}

Source: Data analysis, 2016

Based on the result of intersect (patch) maps between the calculation of social vulnerability with Hazard Prone Area Map can be concluded that there are several villages which have a high vulnerability because it is located in areas prone to disasters and have a high to a moderate social vulnerability (Table 3); the spatial distribution can be seen in Figure 1.

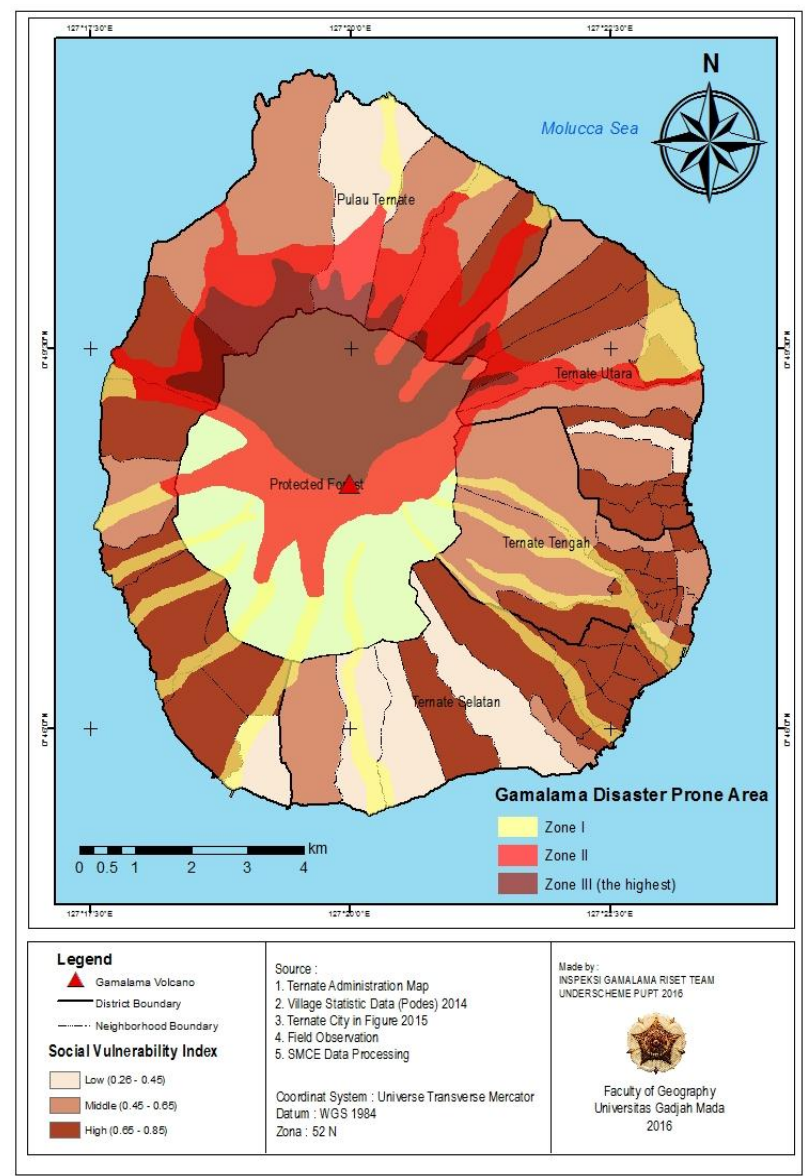

Fig. 1. Social Vulnerability Map and Hazard Prone Area Zone 


\section{B. Economic Vulnerability}

Economic vulnerability is a vulnerability that is measured based on economic condition of a society. According to Cutter et al. (2003) occupation is one of the factors used to measure vulnerability. Job closely related to economic vulnerability because it is associated with a source of income for life. The existence of economic facilities that support economic activity in a region is important to know to analyze vulnerabilities in regional scale. Economic factors as well as social factors are factors that can be the element of risk and can also be a contributor to the capacity of the community in times of disaster. In this study, the economic factor is assumed as a matter of supporting community capacity.

The value of social vulnerability of Ternate Island's community is obtained after data processing and weighting for each variable and parameter. The calculation result of the social vulnerability of Ternate Island community informed that the majority of villages in Ternate Island has a moderate economic vulnerability ( 25 villages), while 18 villages have low susceptibility and the rest (16 villages) have a high susceptibility. This shows that the value of economic sector is quite good. Nonetheless, it still needs a great concern in disaster risk reduction. Improvement of community capacity in the economic sector accompanied by the development of economic infrastructure can be an alternative to reduce the vulnerability of the local economy.

Considering the many villages that have high economic vulnerability, it is necessary to give priority to where village should be given attention first. Villages which should take priority in advance is a village with a high economic vulnerability and are in Hazard Prone Area III followed Hazard Prone Area II and Hazard Prone Area I in because it has a greater vulnerability to disasters.

TABLE IV. VILLAGES WITH THE ECONOMIC VULNERABILITY AND VULNERABILITY TO GAMALAMA VOLCANO ERUPTION

\begin{tabular}{|l|l|l|}
\hline \multicolumn{1}{|c|}{ Village } & \multicolumn{1}{c|}{$\begin{array}{c}\text { Economic } \\
\text { Vulnerability }\end{array}$} & \multicolumn{1}{c|}{ Zone } \\
\hline Loto & High & III, II, I \\
\hline Togafo & High & II, I \\
\hline Takome & Middle & II, I \\
\hline Tobololo & Middle & III, II, I \\
\hline Sulamadaha & High & III, II, I \\
\hline Bula & High & II, I \\
\hline Kurlaba & High & III, II, I \\
\hline Tarau & Middle & III, II \\
\hline Sango & Middle & III, II \\
\hline Tabam & Middle & III, II, I \\
\hline Tubo & High & III, II, I \\
\hline
\end{tabular}

Based on the result of intersect (patch) map between economic vulnerability map with Hazard Prone Area Map (Figure 2) it is figured that there are high vulnerability villages because they are located in disaster-prone areas and has a high to a moderate economic vulnerability (Table IV).

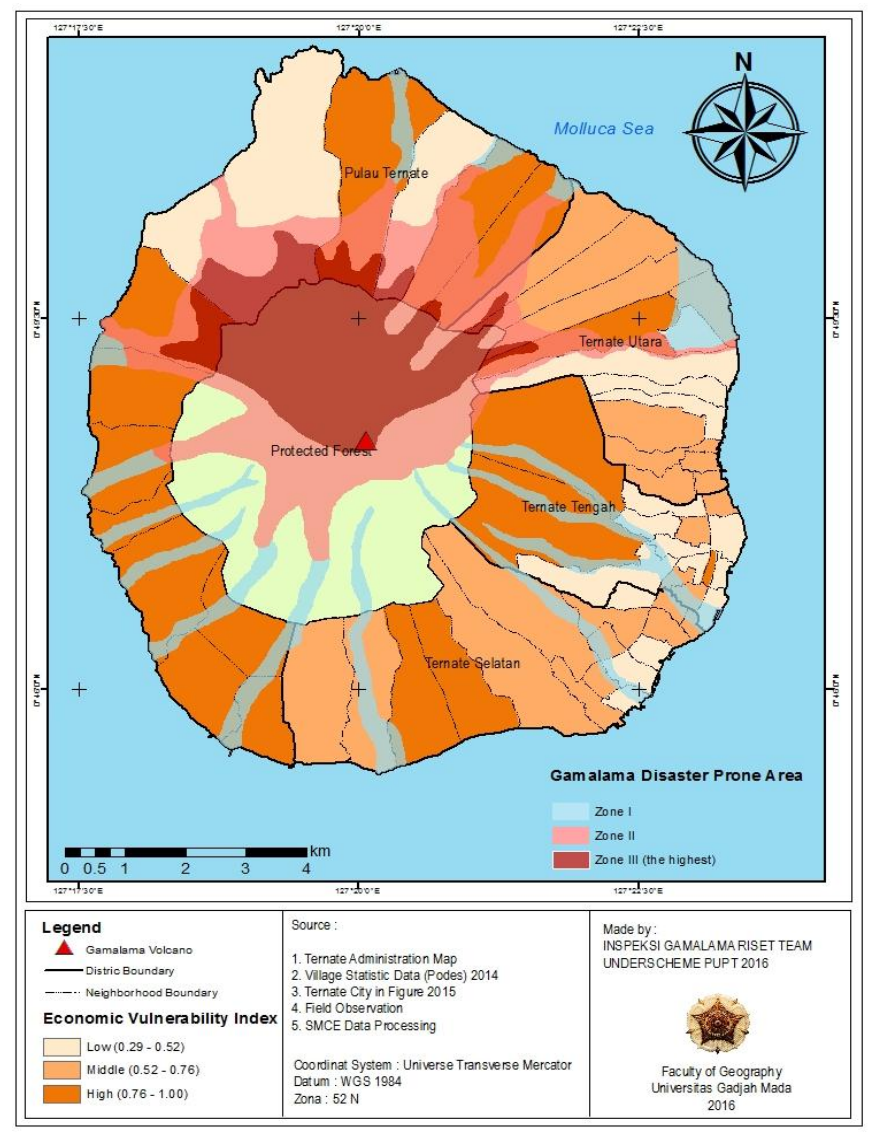

Fig. 2. Economic Vulnerability Map and Hazard Prone Area Zone

\section{Physical Vulnerability}

Physical vulnerability (infrastructure) describes a physical condition (infrastructure) that are prone to certain hazard factor (Bakornas, 2007). Physical vulnerability associated with the presence of existing infrastructure in the Hazard Prone Area. In general physical vulnerability is related to settlement infrastructure of a person or society on a Hazard Prone Areas. Some indicators in this vulnerability analisys are:

- The percentage of built up area

- Percentage of building types

- Electric network

- The ratio of the road's length

- Telecommunications networks

- Taps network

Physical vulnerability is defined as vulnerability to disaster to the urban's physical aspects. Urban's physic is related to infrastructure to support the activities of the population. This vulnerability is defined as the elaboration of physical vulnerability from the perspective of the Law on Spatial Planning and the practical concept of the vulnerability of disaster from the physical aspect. From the Law on Spatial Planning perspectives are translated according to the types of infrastructure forming the structure of urban space that is the road network, electricity networks, water networks, telecommunication networks, waste system, drainage systems, sanitation networks and also a means of urban as well as a means of trade, services, education, health and others. 
Meanwhile, from the perspective of practical concepts, some of the variables associated with physical vulnerability are the percentage of built up area, the percentage of buildings, electricity networks, road networks, telecommunication networks and taps network.

The results primary and secondary data processing from each village shows that Ternate Island is a region with a high risk of Gamalama Volcanic eruption and also cold lava flood. This is indicated by the level of vulnerability in this region to be dominated by a high degree of vulnerability. Table 5 outlines the physical vulnerability in Ternate Island which divided into three levels of vulnerability. The high level of vulnerability was found in 25 villages of 59 villages in this island, or as much as $42.38 \%$. The high degree of vulnerability is due to the location of Gamalama Volcano, which is in the middle of the island, and the distance between the foot of the mountain to the residents is not so far. Therefore, the level of physical vulnerability in Ternate Island can be categorized as relatively high.

TABLE V. DISTRIBUTION OF PHYSICAL VULNERABILITY LEVEL

\begin{tabular}{|l|l|l|l|}
\hline No & Level of Vulnerabiliy & Number of Villages & $\begin{array}{c}\text { Percentage } \\
(\%)\end{array}$ \\
\hline 1. & Low & 17 & 28,81 \\
\hline 2. & Middle & 17 & 28,81 \\
\hline 3. & High & 25 & 42,38 \\
\hline \multicolumn{2}{|c|}{ Total } & 59 & 100 \\
\hline \multicolumn{2}{|c|}{ Source : Data analysis, 2016 } \\
\hline
\end{tabular}

Distribution of the vulnerability in Ternate Island, as shown in Figure 3, is that the high degree of vulnerability is in the east of the island, more precisely at most villages in Ternate Tengah District. Those villages are more defined by the villages in urban areas, because those villages are located in the east of the island (classified as urban areas) with the availability of facilities and infrastructure which is more complete than other regions. This causes the vulnerability level is higher even though the variables used in the study of physical vulnerability, which is the average width of roads, electricity grids and telecommunications networks, is better seen as a capacity compared to one element of risk. Thus, in this study it can be concluded that the areas included in the urban areas, which have the more complete infrastructure and facilities, have higher levels of vulnerability because they have more density of buildings and more population. However, the vulnerability can be addressed with complete facilities and infrastructure which seen as the capacity (due to community preparedness tends to be higher).

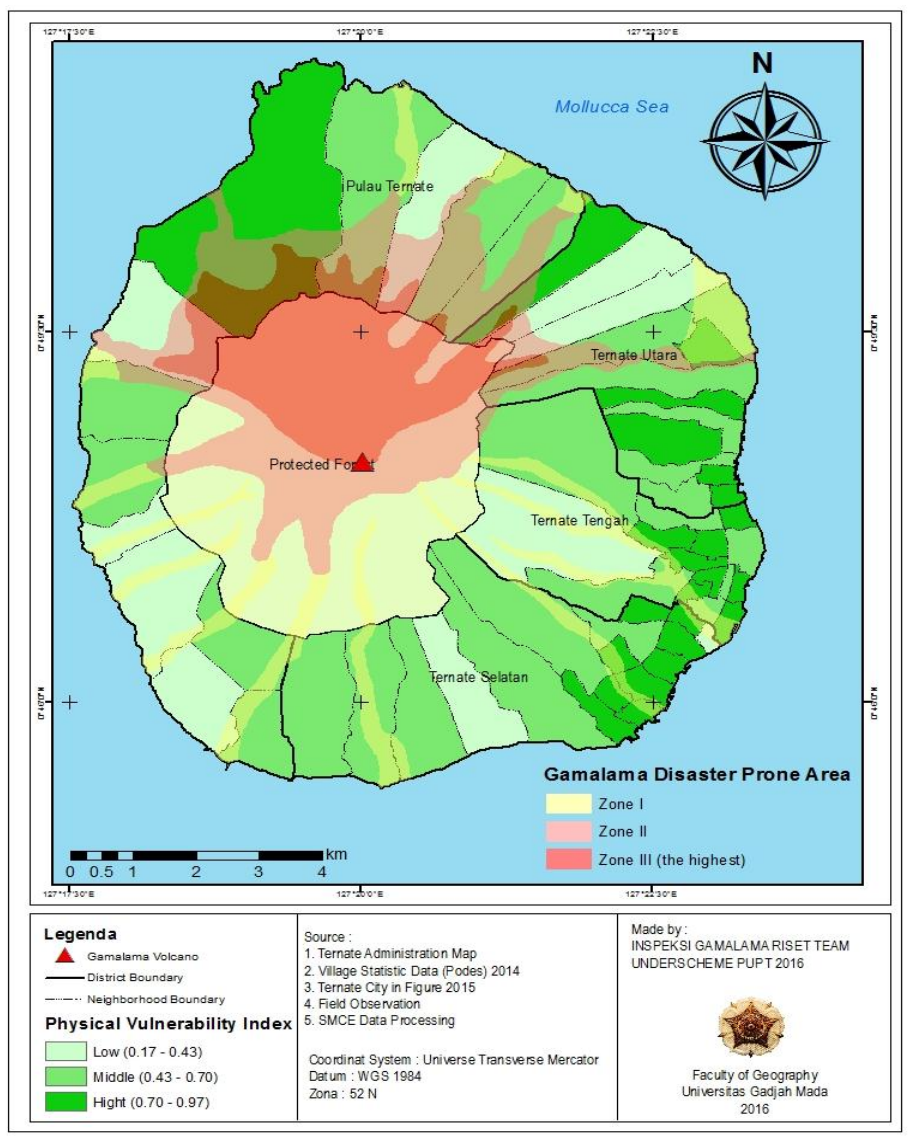

Fig. 3. Physical Vulnerability Map and Hazard Prone Area Zone

Based on the calculations, the weight of physical vulnerability in Ternate Island is 0.11 . Then, from the weights can be concluded that the level of physical vulnerability of Ubo-Obo Village in the District of Ternate Selatan levels is highest (0.97) while the lowest is in Marikurubu Village in the District of Ternate Tengah with a value of 0, 17 (Figure 3).

\section{Total Vulnerability}

The total of vulnerability in this study is resulted from a composite of social, economic and physical vulnerability index, each of which has been weighted in accordance with the level of interest in the vulnerability. The weighting is considering the advices from village government representatives, community representatives, as well as BPBD's representatives then calculated by the method of ranking and treated with ILWIS through rank ordering method. The result is shown in Table 6.

\section{TABLE VI. RESULT CALCULATION OF TOTAL VULNERABILITY}

\begin{tabular}{|c|l|l|c|c|c|c|}
\hline No. & District & Village & $\begin{array}{c}\text { Economic } \\
\text { Vulnerabilit } \\
\mathbf{y}(\mathbf{0 . 6 1})\end{array}$ & $\begin{array}{c}\text { Social } \\
\text { Vulnerability } \\
(\mathbf{0 . 2 7 8})\end{array}$ & $\begin{array}{c}\text { Physical } \\
\text { Vulnerability } \\
(\mathbf{0 . 1 1})\end{array}$ & $\begin{array}{c}\text { Total } \\
\text { Vulnerability }\end{array}$ \\
\hline 1 & $\begin{array}{l}\text { Pulau } \\
\text { Ternate }\end{array}$ & Tobololo & 0,47 & 0,59 & 0,31 & $\mathbf{0 , 4 8 6}$ \\
\hline 2 & $\begin{array}{l}\text { Pulau } \\
\text { Ternate }\end{array}$ & Takome & 0,51 & 0,50 & 0,82 & $\mathbf{0 , 5 4 1 3}$ \\
\hline 3 & $\begin{array}{l}\text { Pulau } \\
\text { Ternate }\end{array}$ & $\begin{array}{l}\text { Sulamada } \\
\text { ha }\end{array}$ & 0,87 & 0,49 & 0,34 & $\mathbf{0 , 7 0 5 3}$ \\
\hline 4 & $\begin{array}{l}\text { Pulau } \\
\text { Ternate }\end{array}$ & Jambula & 0,94 & 0,38 & 0,34 & $\mathbf{0 , 7 1 7 2}$ \\
\hline 5 & $\begin{array}{l}\text { Pulau } \\
\text { Ternate }\end{array}$ & Kulaba & 0,87 & 0,62 & 0,39 & $\mathbf{0 , 7 4 7 2}$ \\
\hline 6 & Pulau & Kastela & 0,92 & 0,63 & 0,22 & $\mathbf{0 , 7 6 1 8}$ \\
\hline
\end{tabular}




\begin{tabular}{|c|c|c|c|c|c|c|}
\hline No. & District & Village & $\begin{array}{c}\text { Economic } \\
\text { Vulnerabilit } \\
\text { y (0.61) }\end{array}$ & $\begin{array}{c}\text { Social } \\
\text { Vulnerability } \\
(\mathbf{0 . 2 2 7 8}) \\
\end{array}$ & $\begin{array}{c}\text { Physical } \\
\text { Vulnerability } \\
(\mathbf{0 . 1 1})\end{array}$ & $\begin{array}{c}\text { Total } \\
\text { Vulnerability }\end{array}$ \\
\hline & Ternate & & & & & \\
\hline 7 & $\begin{array}{l}\text { Pulau } \\
\text { Ternate }\end{array}$ & Loto & 0,94 & 0,63 & 0,19 & 0,7707 \\
\hline 8 & $\begin{array}{l}\text { Pulau } \\
\text { Ternate }\end{array}$ & $\begin{array}{l}\text { Afetadum } \\
\text { a }\end{array}$ & 0,94 & 0,58 & 0,36 & 0,7754 \\
\hline 9 & $\begin{array}{l}\text { Pulau } \\
\text { Ternate }\end{array}$ & Bula & 0,94 & 0,59 & 0,38 & 0,7804 \\
\hline 10 & $\begin{array}{l}\text { Pulau } \\
\text { Ternate }\end{array}$ & Rua & 0,94 & 0,68 & 0,22 & 0,788 \\
\hline 11 & $\begin{array}{l}\text { Pulau } \\
\text { Ternate }\end{array}$ & Dorpedu & 0,94 & 0,66 & 0,33 & 0,7945 \\
\hline 12 & $\begin{array}{l}\text { Pulau } \\
\text { Ternate }\end{array}$ & $\begin{array}{l}\text { Foramadi } \\
\text { ahi }\end{array}$ & 0,94 & 0,66 & 0,36 & 0,7978 \\
\hline 13 & $\begin{array}{l}\text { Pulau } \\
\text { Ternate }\end{array}$ & Togafo & 0,94 & 0,66 & 0,36 & 0,7978 \\
\hline 14 & $\begin{array}{l}\text { Ternate } \\
\text { Selatan }\end{array}$ & $\begin{array}{l}\text { Bastiong } \\
\text { Talangam } \\
\mathrm{e} \\
\end{array}$ & 0,29 & 0,62 & 0,81 & 0,4396 \\
\hline 15 & $\begin{array}{l}\text { Ternate } \\
\text { Selatan }\end{array}$ & $\begin{array}{l}\text { Tanah } \\
\text { Tinggi } \\
\text { Barat }\end{array}$ & 0,33 & 0,74 & 0,83 & 0,4998 \\
\hline 16 & $\begin{array}{l}\text { Ternate } \\
\text { Selatan }\end{array}$ & Kalumata & 0,63 & 0,26 & 0,64 & 0,5275 \\
\hline 17 & $\begin{array}{l}\text { Ternate } \\
\text { Selatan } \\
\end{array}$ & $\begin{array}{l}\text { Bastiong } \\
\text { Karance }\end{array}$ & 0,41 & 0,76 & 0,81 & 0,552 \\
\hline 18 & $\begin{array}{l}\text { Ternate } \\
\text { Selatan } \\
\end{array}$ & Sasa & 0,64 & 0,60 & 0,37 & 0,5991 \\
\hline 19 & $\begin{array}{l}\text { Ternate } \\
\text { Selatan }\end{array}$ & Gambesi & 0,79 & 0,33 & 0,34 & 0,6117 \\
\hline 20 & $\begin{array}{l}\text { Ternate } \\
\text { Selatan }\end{array}$ & $\begin{array}{l}\text { Mangga } \\
\text { Dua }\end{array}$ & 0,55 & 0,67 & 0,94 & 0,6265 \\
\hline 21 & $\begin{array}{l}\text { Ternate } \\
\text { Selatan }\end{array}$ & Toboko & 0,72 & 0,66 & 0,23 & 0,6493 \\
\hline 22 & $\begin{array}{l}\text { Ternate } \\
\text { Selatan }\end{array}$ & $\begin{array}{l}\text { Kayu } \\
\text { Merah }\end{array}$ & 0,73 & 0,50 & 0,94 & 0,6887 \\
\hline 23 & $\begin{array}{l}\text { Ternate } \\
\text { Selatan } \\
\end{array}$ & $\begin{array}{l}\text { Jati } \\
\text { Perumnas } \\
\end{array}$ & 0,73 & 0,62 & 0,64 & 0,6893 \\
\hline 24 & $\begin{array}{l}\text { Ternate } \\
\text { Selatan } \\
\end{array}$ & Jati & 0,73 & 0,64 & 0,64 & 0,6949 \\
\hline 25 & $\begin{array}{l}\text { Ternate } \\
\text { Selatan }\end{array}$ & Ubo-Ubo & 0,63 & 0,80 & 0,97 & 0,715 \\
\hline 26 & $\begin{array}{l}\text { Ternate } \\
\text { Selatan }\end{array}$ & Tobona & 0,79 & 0,69 & 0,37 & 0,7158 \\
\hline 27 & $\begin{array}{l}\text { Ternate } \\
\text { Selatan }\end{array}$ & Fitu & 0,94 & 0,43 & 0,37 & 0,7345 \\
\hline 28 & $\begin{array}{l}\text { Ternate } \\
\text { Selatan }\end{array}$ & $\begin{array}{l}\text { Tanah } \\
\text { Tinggi } \\
\end{array}$ & 0,72 & 0,74 & 0,83 & $\mathbf{0 , 7 3 7 7}$ \\
\hline 29 & $\begin{array}{l}\text { Ternate } \\
\text { Selatan }\end{array}$ & $\begin{array}{l}\text { Mangga } \\
\text { Dua } \\
\text { Utara }\end{array}$ & 0,73 & 0,68 & 0,94 & 0,7391 \\
\hline 30 & $\begin{array}{l}\text { Ternate } \\
\text { Selatan }\end{array}$ & Ngade & 0,87 & 0,66 & 0,23 & 0,7408 \\
\hline 31 & $\begin{array}{l}\text { Ternate } \\
\text { Tengah }\end{array}$ & $\begin{array}{l}\text { Gamalam } \\
\text { a }\end{array}$ & 0,29 & 0,60 & 0,64 & 0,4153 \\
\hline 32 & $\begin{array}{l}\text { Ternate } \\
\text { Tengah }\end{array}$ & $\begin{array}{l}\text { Kota } \\
\text { Baru } \\
\end{array}$ & 0,31 & 0,65 & 0,81 & 0,4602 \\
\hline 33 & $\begin{array}{l}\text { Ternate } \\
\text { Tengah }\end{array}$ & Maliaro & 0,38 & 0,64 & 0,49 & 0,4649 \\
\hline 34 & $\begin{array}{l}\text { Ternate } \\
\text { Tengah }\end{array}$ & Muhajirin & 0,38 & 0,60 & 0,69 & 0,4757 \\
\hline 35 & $\begin{array}{l}\text { Ternate } \\
\text { Tengah }\end{array}$ & $\begin{array}{l}\text { Kalumpa } \\
\text { ng }\end{array}$ & 0,36 & 0,63 & 0,81 & 0,4851 \\
\hline 36 & $\begin{array}{l}\text { Ternate } \\
\text { Tengah }\end{array}$ & $\begin{array}{l}\text { Makassar } \\
\text { Barat }\end{array}$ & 0,54 & 0,59 & 0,5 & 0,5496 \\
\hline 37 & $\begin{array}{l}\text { Ternate } \\
\text { Tengah }\end{array}$ & $\begin{array}{l}\text { Tanah } \\
\text { Raja } \\
\end{array}$ & 0,56 & 0,76 & 0,38 & 0,5962 \\
\hline 38 & $\begin{array}{l}\text { Ternate } \\
\text { Tengah }\end{array}$ & Takoma & 0,62 & 0,61 & 0,52 & 0,6062 \\
\hline 39 & $\begin{array}{l}\text { Ternate } \\
\text { Tengah } \\
\end{array}$ & $\begin{array}{l}\text { Makassar } \\
\text { Timur } \\
\end{array}$ & 0,6 & 0,66 & 0,67 & 0,6245 \\
\hline 40 & $\begin{array}{l}\text { Ternate } \\
\text { Tengah }\end{array}$ & Salahudin & 0,54 & 0,69 & 0,94 & 0,626 \\
\hline 41 & $\begin{array}{l}\text { Ternate } \\
\text { Tengah }\end{array}$ & Stadion & 0,56 & 0,77 & 0,68 & 0,632 \\
\hline 42 & $\begin{array}{l}\text { Ternate } \\
\text { Tengah }\end{array}$ & $\begin{array}{l}\text { Kampung } \\
\text { Pisang }\end{array}$ & 0,67 & 0,75 & 0,83 & 0,71 \\
\hline 43 & $\begin{array}{l}\text { Ternate } \\
\text { Tengah }\end{array}$ & $\begin{array}{l}\text { Marikuru } \\
\text { bu }\end{array}$ & 0,87 & 0,59 & 0,17 & 0,7146 \\
\hline 44 & $\begin{array}{l}\text { Ternate } \\
\text { Tengah } \\
\end{array}$ & Santiong & 0,78 & 0,85 & 0,67 & 0,7875 \\
\hline 45 & $\begin{array}{l}\text { Ternate } \\
\text { Tengah }\end{array}$ & Moya & 1 & 0,51 & 0,36 & 0,7924 \\
\hline 46 & $\begin{array}{l}\text { Ternate } \\
\text { Utara }\end{array}$ & Sangaji & 0,49 & 0,46 & 0,61 & 0,4948 \\
\hline 47 & $\begin{array}{l}\text { Ternate } \\
\text { Utara }\end{array}$ & $\begin{array}{l}\text { Dufa- } \\
\text { Dufa }\end{array}$ & 0,56 & 0,59 & 0,61 & 0,5739 \\
\hline 48 & $\begin{array}{l}\text { Ternate } \\
\text { Utara }\end{array}$ & Tafure & 0,65 & 0,50 & 0,36 & 0,5761 \\
\hline 49 & $\begin{array}{l}\text { Ternate } \\
\text { Utara }\end{array}$ & Akehuda & 0,47 & 0,68 & 0,92 & 0,5783 \\
\hline
\end{tabular}

\begin{tabular}{|c|l|l|c|c|c|c|}
\hline No. & District & Village & $\begin{array}{c}\text { Economic } \\
\text { Vulnerabilit } \\
\mathbf{y}(\mathbf{0 . 6 1})\end{array}$ & $\begin{array}{c}\text { Social } \\
\text { Vulnerability } \\
(\mathbf{0 . 2 7 8})\end{array}$ & $\begin{array}{c}\text { Physical } \\
\text { Vulnerability } \\
(\mathbf{0 . 1 1})\end{array}$ & $\begin{array}{c}\text { Total } \\
\text { Vulnerability }\end{array}$ \\
\hline 50 & $\begin{array}{l}\text { Ternate } \\
\text { Utara }\end{array}$ & Tabam & 0,65 & 0,62 & 0,23 & $\mathbf{0 , 5 9 5 4}$ \\
\hline 51 & $\begin{array}{l}\text { Ternate } \\
\text { Utara }\end{array}$ & Toboleu & 0,59 & 0,56 & 0,82 & $\mathbf{0 , 6 0 6 9}$ \\
\hline 52 & $\begin{array}{l}\text { Ternate } \\
\text { Utara }\end{array}$ & Sango & 0,65 & 0,67 & 0,21 & $\mathbf{0 , 6 0 7 2}$ \\
\hline 53 & $\begin{array}{l}\text { Ternate } \\
\text { Utara }\end{array}$ & Kasturian & 0,62 & 0,66 & 0,49 & $\mathbf{0 , 6 1 6 9}$ \\
\hline 54 & $\begin{array}{l}\text { Ternate } \\
\text { Utara }\end{array}$ & $\begin{array}{l}\text { Sangaji } \\
\text { Utara }\end{array}$ & 0,57 & 0,74 & 0,67 & $\mathbf{0 , 6 2 8 6}$ \\
\hline 55 & $\begin{array}{l}\text { Ternate } \\
\text { Utara }\end{array}$ & Soa & 0,65 & 0,67 & 0,47 & $\mathbf{0 , 6 3 5 8}$ \\
\hline 56 & $\begin{array}{l}\text { Ternate } \\
\text { Utara }\end{array}$ & Tarau & 0,67 & 0,55 & 0,81 & $\mathbf{0 , 6 5 1 8}$ \\
\hline 57 & $\begin{array}{l}\text { Ternate } \\
\text { Utara }\end{array}$ & Salero & 0,65 & 0,79 & 0,77 & $\mathbf{0 , 7 0 2 4}$ \\
\hline 58 & $\begin{array}{l}\text { Ternate } \\
\text { Utara }\end{array}$ & Soasio & 0,72 & 0,71 & 0,68 & $\mathbf{0 , 7 1 2 8}$ \\
\hline 59 & $\begin{array}{l}\text { Ternate } \\
\text { Utara }\end{array}$ & Tubo & 0,92 & 0,51 & 0,34 & $\mathbf{0 , 7 4 1 4}$ \\
\hline
\end{tabular}

Table 6 shows that villages with a total value of highest vulnerability is Foramadiahi Village and Togafo Village with 0.7978 vulnerability index and villages with the lowest total of vulnerability is Gamalama Village (District of Ternate Tengah) with 0.4396 vulnerability index.

Togafo Village that has the highest index of total vulnerability lies in the northwest of Gamalama Volcano and some of its territory is in Gamalama Volcano Disaster-Prone Areas both in KRB I, II, and III (Figure 4). Togafo Village also fed by barangka tipped in Gamalama Volcano. At the time of the eruption, followed by rain, the Togafo Village was threatened by lava flows. 


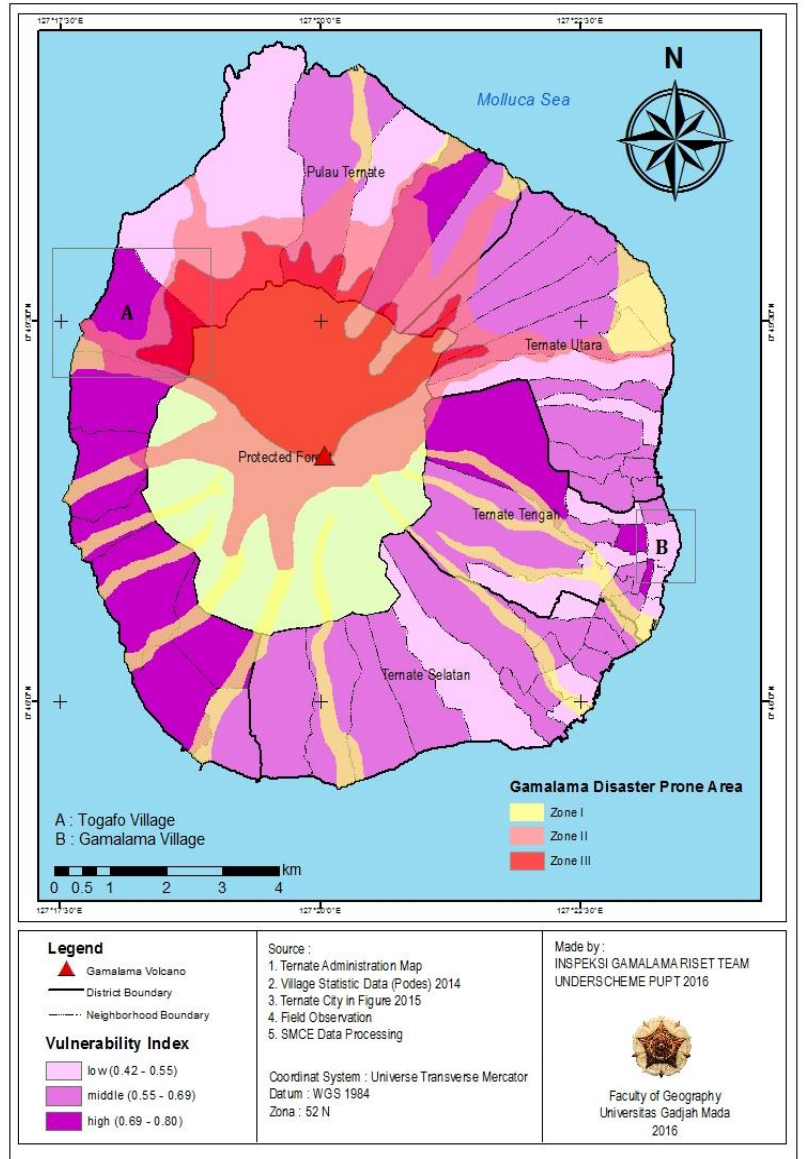

Fig. 4. Total Vulnerability Map and Hazard Prone Area Zone

The existence of Togafo Village which has the highest total of vulnerability and located in Gamalama Volcano Hazard Prone Areas shows that this village is prone affected by eruption: socially, physically and economically. This village's location that relatively far from the Ternate's CBD led to the limitation of social and economic facilities that support efforts to increase community capacity. Similarly, the presence of physical infrastructure, although the density of the population in Togafo Village is relatively low compared to villages in the center of Ternate but the people in this village also needs to access all of the facilities. Nevertheless, the existence of the facility is directly proportional to the direction of urban development, where the development of the city on the island of Ternate tend to occur in urban areas in the east to southeast Gamalama Volcano, while area of west or north of Gamalama Volcano functioned more as an agricultural area.

Gamalama village in the District of Ternate Tengah has the lowest value of total vulnerability, and when viewed in the map of disaster-prone areas, Gamalama Village is not located in a prone area. Gamalama Village located in the southeastern part of Gamalama Volcano and located in the heart of Ternate City. The location is safe from the threat of Gamalama Volcano, the slope is relatively flat and has very good access to lead this district into one of the villages that have a good level of development of the region compared to others. Along with the development of the region led to the availability of physical, social and economic facilities adequately for community and be a reference to other regions.

\section{CONCLUSION AND SUGESTIONS}

Through vulnerability assessment concluded that:

- The villages that have the highest social vulnerability are Loto, Togafo, Kurlaba, Sango, and Tabam.

- The villages that have the highest economic vulnerability are Loto, Togafo, Sulamadaha, Bula, Kurlaba, and Tubo.

- The village that has the highest physical vulnerability is Ubo-Obo Village (District of Ternate Selatan).

- The villages that have the highest total vulnerability are Foramadiahi and Togafo.

Suggestions to the research or disaster management activity of Gamalama Volcano in Ternate City are:

- The government should pay more attention to the villages which have the high social, economic or physical vulnerability, especially also lies in Hazard Prone Area III.

- The government should reduce the vulnerability by doing some programs related to equal city development due the fact that the rapid city development still centred in the east and south part of Ternate Island.

- Since the research or publication on Gamalama Volcano disaster is still very limited, the results of this study are expected to be one of the inputs to the relevant agencies (BPBD of Ternate) in Gamalama Volcano Disaster Risk Reduction (DRR).

\section{REFERENCES}

[1] Adger, W. N., Brooks, N., Bentham, G. and Agnew, M. (2004) 'New indicators of vulnerability and adaptive capacity', Change, (January).

[2] Bakornas (2007) Pengenalan Karakteristik Bencana dan Upaya Mitigasinya di Indonesia.

[3] Balgos, B., Gaillard, J. C. and Sanz, K. (2012) 'The warias of Indonesia in disaster risk reduction: the case of the $2010 \mathrm{Mt}$ Merapi eruption in Indonesia', Gender \& Development. Routledge, 20(2), pp. 337-348. doi: $10.1080 / 13552074.2012 .687218$.

[4] Carver, S. (1991) 'Integrating multi-criteria evaluation with geographical information systems', International journal of geographical information systems, 5(3), pp. 321-339. doi: $10.1080 / 02693799108927858$.

[5] Chester, D. K., Degg, M., Duncan, A. M. and Guest, J. E. (2000) 'The increasing exposure of cities to the effects of volcanic eruptions: a global survey', Global Environmental Change Part B: Environmental Hazards, 2(3), pp. 89-103. doi: 10.1016/S1464-2867(01)00004-3.

[6] Cutter, S. L., Carolina, S., Boruff, B. J. and Shirley, W. L. (2003) 'Social Vulnerability to Environmental Hazards n', Social Science, 84(2).

[7] Gogarten, E. (1918) Die Vulkane der nördlichen Molukken. De Gruyter.

[8] Lassa, J. (2010) 'Global governance of disaster risk reduction: an introduction to a new analytical framework', Global: International Politics Journal, 10(1), pp. 17-27.

[9] Malczewski, J. (2004) 'GIS-based land-use suitability analysis: A critical overview', Progress in Planning, 62(1), pp. 3-65. doi: 10.1016/j.progress.2003.09.002.

[10] Marfai, M. A. and King, L. (2008) 'Tidal inundation mapping under enhanced land subsidence in Semarang, Central Java Indonesia', 
Natural Hazards, 44(1), pp. 93-109. doi: 10.1007/s11069-007-9144-z.

[11] Mei, E. T. W. and Lavigne, F. (2012) 'Influence of the institutional and socio-economic context for responding to disasters: case study of the 1994 and 2006 eruptions of the Merapi Volcano, Indonesia', Geological Society, London, Special Publications, 361(1), pp. 171-186. doi: 10.1144/SP361.14.

[12] Mei, E. T. W., Lavigne, F., Picquout, A., de Bélizal, E., Brunstein, D., Grancher, D., Sartohadi, J., Cholik, N. and Vidal, C. (2013) 'Lessons learned from the 2010 evacuations at Merapi volcano', Journal of Volcanology and Geothermal Research. Elsevier B.V., 261, pp. 348365. doi: 10.1016/j.jvolgeores.2013.03.010.

[13] Small, C. and Naumann, T. (2001) 'The global distribution of human population and recent volcanism', Global Environmental Change Part B: Environmental Hazards, 3(3-4), pp. 93-109. doi: 10.1016/S14642867(02)00002-5.

[14] Sri Hadmoko, D. (2009) Les mouvements de versant dans les Mont Menoreh, Java, Indonésie: variabilité spatio-temporelle, impacts, déclenchement, et analyse de susceptibilité. THES.

[15] UNISDR (2011) The 2011 Global Assessment Report on Disaster Risk Reduction: Revealing Risk, Redefining Development (Summary and Main Finding).

[16] Van Westen, C. . (2016) 'Spatial information for analyzing changing hydro - meteorological risk', in Remote sensing, natural hazards and environmental change, pp. 73-76

[17] Wisner, B., Gaillard, J. C. and Kelman, I. (2012) 'Framing disaster: Theories and stories seeking to understand hazards , vulnerability and risk', Handbook of Hazards and Disaster Risk Reduction, pp. 18-33. doi: 10.4324/9781315689081. 